\title{
Prediction of Flexible Pavement Deflection Based on Falling Weight Deflectometer, FWD, for Highways Traversed by Heavy Overloaded Vehicles (Case Study on Arterial And Collector Roads in Tuban, East Java, Indonesia)
}

\author{
Catur Arif Prastyanto ${ }^{1, a}$, Indrasurya B. Mochtar ${ }^{2, b}$ \\ ${ }^{1,2}$ Department of Civil Engineering, Institut Teknologi Sepuluh Nopember, Indonesia \\ a cprastyanto@gmail.com,
}

\begin{abstract}
Falling Weight Deflectometer, FWD, is the most popular equipment used to measure the deflection of flexible pavement in Indonesia. The loading used during application of the FWD equipment generally correlates directly with those of the loads of standard heavy vehicles. Therefore, the resulted pavement deflections obtained from the tests should be also suitable for highways traversed by standard normal vehicles only. This may not be the case for highways in Indonesia, where most trucks are highly overloaded, so much beyond the allowable standard loads. The existing method of FWD test may not be representative anymore to measure the actual pavement deflections under highly overloaded vehicles. In this paper, the authors describe their findings about deflections of flexible pavement when the pavements were subjected by heavily overloaded vehicles. The first step is to modify the FWD equipment with larger falling distances and heavier loads to simulate the highly overloaded vehicles in Indonesia. Based on the results and by using statistical approach, a new mathematical equation can be derived to reflect the functions of actual pavement deflections under much higher loads when compared to those of standard normal load. Therefore, using this new equation one can predict the actual pavement deflection under highly overloaded vehicles, by just performing standard FWD test of standard loads on the pavement, so that the design of overlay thickness can be modified accordingly to be applicable to overloaded traffic in Indonesia.
\end{abstract}

Keywords - pavement deflection, falling weight deflectometer, FWD, pavement overlay, overloaded heavy vehicles.

\section{INTRODUCTION}

$\mathrm{F}$ or designing thickness of flexible pavements, Bina Marga (2005) [1] has presented a guidance that one of the data used for the design is the deflection of the pavement under vehicle load. In this guidance, it is mentioned that the pavement deflections can be obtained from rebound deflections data using the Benkelmen Beam, BB, Test, or from pavement deflection measurement of the Falling Weight Deflectometer, FWD, Test. Currently in Indonesia, the Falling Weight Deflectometer, FWD, Test is still the more widely used one than the Benkelmen Beam, BB, Test. The results of pavement deflection test using the FWD Test have been accepted widely as sufficiently satisfactory (AASHTO, 1993 [2]; Asphalt Institute, 1981 [3]; FHWA, 2003 [4], Huang, 2004 [5]; Kosasih, 2003 [6]; Shell, 1978 [7]).

When testing the pavement deflection using the FWD equipment, usually the load used during the deflection measurement is 4.08 tons $(=40 \mathrm{kN}=9000 \mathrm{lbs}$. $)$ This FWD load is to represent the load of one side of the tire load, which is half the standard axle load of 8.16 tons (= $80 \mathrm{kN}=18000 \mathrm{lbs}$.) ([1]; [2]). The test results using the above load generally can be correlated with a loading under tire pressure of about $580 \mathrm{kPa}$ (about $90 \mathrm{psi}$.) and in the authors opinion the pavement deflection obtained will merely represent the deflection under normal truck loading only. Therefore, when the results will be used to design thickness of pavement overlays for flexible pavements, the thickness should therefore representative for roads and highways that are traversed by vehicles with normal loadings only.
Sutikno and Mochtar (1991) [8] during their study on several highway sections in East Java, Indonesia, had stated that about $48.98 \%$ of the single axle loads of truck traffic using the highways were overloaded to higher than 10.5 tons $(=$ the threshold for maximum single axle load in Indonesia). Similar study of Prastyanto et.al. (2012, [9]) with heavy vehicles carrying building materials on a stretch of highway between Jenu - Tuban, East Java, also showed that $100 \%$ of the heavy vehicles could be considered as overloaded, some of them are even extremely overloaded. This condition showed that the actual deflections of pavement in reality in Indonesia were much larger than those measured by means of the FWD test.

Based on the above reasoning, the authors perceived that the current FWD Test was no longer satisfactory to represent the pavement deflection and the overlay design for the mostly overloaded conditions of roads and highways in Indonesia. Heavier loads of the FWD equipment should be tried. In this study, the authors attempted to find the "true pictures" of flexible pavement deflections in field using modified FWD test apparatus, on several arterial and collector highways in East Java, with variety of loading from the below-standard load, standard load, to the excessive load that currently prevailing on Indonesian roads. The highways selected were those observed to have mostly overloaded truck traffic to use the highways. The results of this study is expected to be used to predict the actual pavement deflections under overloaded vehicles, so that the pavement design thickness for overlays can be modified accordingly. 


\section{METHODS}

The methods used in this study can be divided into 2 (two) stages, which are:

1. Testing of pavement deflection using the FWD equipment.

To obtain the values of pavement deflection, the pavements were given impulse loads through a steel plate with diameter $300 \mathrm{~mm}(=30 \mathrm{~cm})$, which was specific for flexible pavements. When the loads were dropped, the pavements would also be subjected to vibrational load, and the vibrations were recorded by special geophone equipment that were located at several interval locations around the pavement surface. In this study, the estimated total pavement thickness ranged between $700-1000 \mathrm{~mm}$, and the geophones were set at distances of $0 \mathrm{~mm}, 300,600,750,900,1200$, and 1500 $\mathrm{mm}$ from the center of impact load (Danida,1990) [10]), which can be illustrated as in Figure 1.

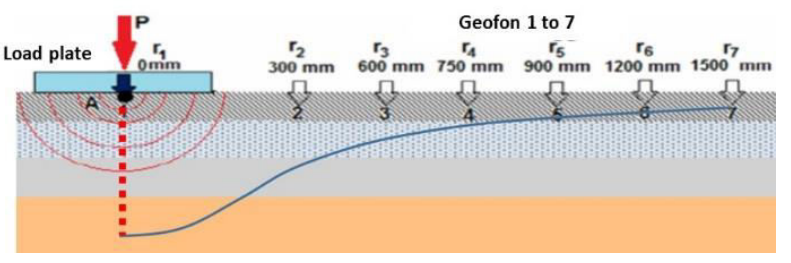

Figure 1. Locations of the geophones during pavement deflection test using the FWD equipment.

The loading used during the FWD Test consisted of 6 variations of loading, which were: one loading below the standard load, one loading of standard load, and 4 loadings above the standard load. Inside the Dynatest FWD Manual Version 242 [11] it was explained clearly the methods of testing and the setting of loading and heights of the hammer drops. There were 4 (four) settings of hammer drop in the FWD Manual, which were $50 \mathrm{~mm}(=\mathrm{h} 1), 100 \mathrm{~mm}(=\mathrm{h} 2), 200 \mathrm{~mm}(=\mathrm{h} 3)$, and $390 \mathrm{~mm}(=\mathrm{h} 4)$; while the loading used were $50 \mathrm{~kg}, 150$ $\mathrm{kg}, 250 \mathrm{~kg}$, and $350 \mathrm{~kg}$. Modification was made to the equipment by adding the $\mathrm{h} 4$ hammer drop and the $350 \mathrm{~kg}$ range of loading to simulate the excessive loads.

To obtain the target of the expected load, the height of hammer drop could be correlated from the following equation:

$$
\mathrm{h}(\mathrm{mm})=(\mathrm{P} \max / \mathrm{k})^{2},
$$

in which the values of Pmax and $\mathrm{k}$ could be seen from Table 1. The values of Pmax = peak load, and $\mathrm{k}$ is stress in $\mathrm{kPa}$ using $300 \mathrm{~mm}$ diameter plate.

In the FWD Manual, there was a special note that the values in Table 1 above were the approximate values only, because the actual loads obtained for the test were actually also depended on the flexural stiffness of the pavement. Therefore, to obtain the most representative loading for pavements, trial should be attempted on the actual pavement surface for the variety of loadings and heights of hammer drop.
Table 1. The approximate values of Pmax and $\mathrm{k}$ for for FWD test

\begin{tabular}{|c|c|c|c|c|c|c|c|}
\hline Mass of Weight & \multicolumn{3}{|c|}{ k (approx.) } & \multicolumn{3}{c|}{ Load Range (approx.) } \\
\hline $\mathbf{k g}$ & $\mathbf{l b s}$ & $\mathbf{k p a} / \mathbf{3 0 0}$ & $\mathbf{k N}$ & $\mathbf{l b f}$ & $\mathbf{k p a} / \mathbf{3 0 0}$ & $\mathbf{k N}$ & lbf \\
\hline 350 & 770 & 85 & 6 & 1350 & $565-1700$ & $40-120$ & $9000-27000$ \\
\hline 250 & 550 & 60 & 4.2 & 935 & $380-1200$ & $27-85$ & $6000-18500$ \\
\hline 150 & 330 & 35 & 2.5 & 550 & $225-700$ & $16-50$ & $3500-11000$ \\
\hline 50 & 110 & 14 & 1 & 220 & $100-270$ & $7-20$ & $1500-4400$ \\
\hline
\end{tabular}

Source : Dynatest FWD/HWD Test Systems, (2008),

Owner's Manual Version 2.4.2.

As explained above, in general the load used for the pavement deflection testing is 4.08 tons $(40 \mathrm{kN})$ of the standard load 8.16 ton. To get the desired loading variation, the things that must be done is to change the loading and the height of the hammer drop in the FWD tool.

Beside the deflection measurements, measurement of the pavement temperatures and weather conditions were also conducted. These measurements were performed to obtain the factors of correction to apply for the deflection measurement due to the changing of temperature and weather. The activities during FWD testing can be seen in Figure 2

\section{Data Analyses.}

The first step in data analyses was to perform correction of the deflection values due to variation in temperature and weather. Bina Marga [1] had given the correlation, so that the corrections could be taken from the following equations:

$>$ Correction of temperature:

$$
\begin{aligned}
& \mathrm{F}_{\mathrm{t}} \quad=14.785 * \mathrm{~T}_{\mathrm{L}}^{-0.7573} \\
& \mathrm{~T}_{\mathrm{L}}=\text { pavement surface temperature }\left({ }^{\circ} \mathrm{C}\right)
\end{aligned}
$$

$>$ Correction of weather

$\mathrm{Ca}=1.2$ (when test was conducted during dry season (no rain); and

0.9 (when test was conducted during wet/rainy season.

The next step was to obtain the mathematical model with 2 variables, which were the vehicle loads (as in $\mathrm{X}$ axis) and the pavement deflection (as in $\mathrm{Y}$ axis). The mathematical model was utilized to find the best statistical model to fit the test results, in which the best model was the one with the correlation factor $\left(\mathrm{R}^{2}\right)$ most approaching 1.0 .

\section{RESULTS AND DISCUSSIONS}

In Figure 1 it was shown that the field test of FWD would result 7 values of deflection data, which were the deflection value of $r_{1}$ to $r_{7}$. Nevertheless, the actual deflection value to be taken into consideration was the largest deflection, which occurred under the deflection value $r_{1}$. As mentioned previously, the loading data from FWD represented only half of the vehicle axle loading. The results of field data test using the FWD are given in Table 2. The axle loading of vehicles (in tons) given in Table 2 were twice the amount of loading used in the FWD test. 

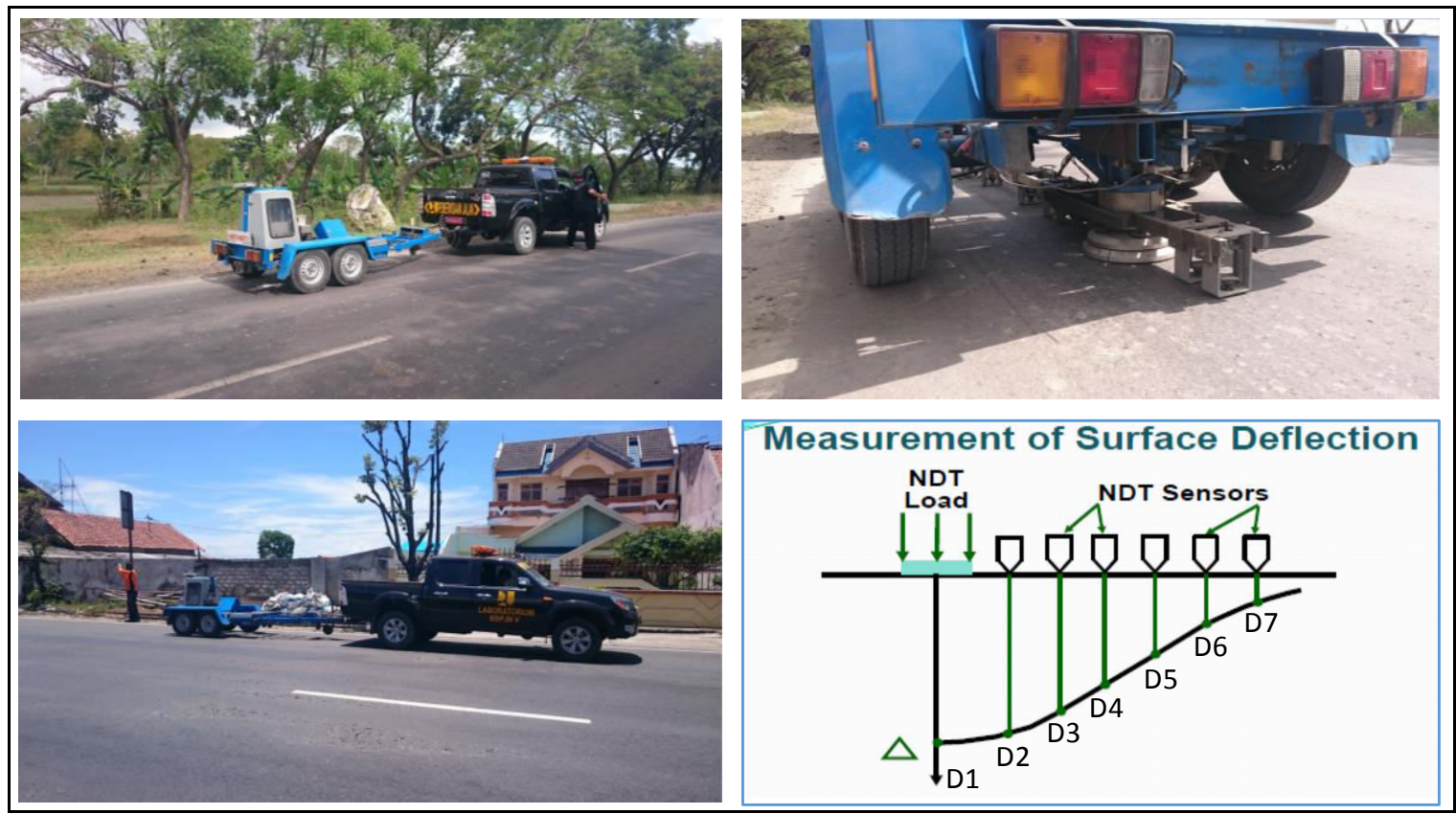

Figure 2. Testing activities during the pavement deflection measurement using the FWD apparatus.

Table 2. Results of the pavement deflection test using FWD

\begin{tabular}{|c|c|c|c|c|c|c|c|c|}
\hline \multirow{2}{*}{$\begin{array}{c}\text { Name of } \\
\text { Road }\end{array}$} & \multirow{2}{*}{$\begin{array}{c}\begin{array}{c}\text { No. of } \\
\text { Test }\end{array} \\
\end{array}$} & \multirow{2}{*}{ Data Recorded } & \multicolumn{6}{|c|}{ Variations of Load } \\
\hline & & & 1 & 2 & 3 & 4 & 5 & 6 \\
\hline \multirow{11}{*}{ Arterial } & \multicolumn{2}{|r|}{ Temp. $\left({ }^{\circ} \mathrm{C}\right)$} & 56.0 & 56.0 & 56.0 & 60.0 & 60.0 & 60.0 \\
\hline & \multirow{2}{*}{1} & Load (ton) & 5.6941 & 8.3331 & 13.8314 & 16.1645 & 17.5350 & 19.6642 \\
\hline & & Deflection (mm) & 0.2606 & 0.3189 & 0.3988 & 0.4667 & 0.5112 & 0.5496 \\
\hline & \multirow{2}{*}{2} & Load (ton) & 5.6553 & 8.3331 & 13.8355 & 16.0993 & 17.5269 & 19.7315 \\
\hline & & Deflection (mm) & 0.1921 & 0.2519 & 0.3910 & 0.4753 & 0.4966 & 0.5445 \\
\hline & \multirow{2}{*}{3} & Load (ton) & 5.5758 & 8.3005 & 13.7784 & 16.2216 & 17.6574 & 19.8865 \\
\hline & & Deflection (mm) & 0.1841 & 0.2338 & 0.4141 & 0.4939 & 0.5006 & 0.5637 \\
\hline & \multirow{2}{*}{4} & Load (ton) & 5.6288 & 8.2883 & 13.6193 & 16.0891 & 17.4188 & 19.6051 \\
\hline & & Deflection (mm) & \begin{tabular}{|l|}
0.1927 \\
\end{tabular} & 0.2288 & 0.4143 & 0.4480 & 0.4971 & 0.5629 \\
\hline & \multirow{2}{*}{5} & Load (ton) & 5.6411 & 8.2964 & 13.6336 & 16.0524 & 17.4188 & 19.6336 \\
\hline & & Deflection (mm) & 0.2126 & 0.2381 & 0.3915 & 0.5002 & 0.5025 & 0.5868 \\
\hline \multirow{11}{*}{ Collector } & \multicolumn{2}{|r|}{ Temp. $\left({ }^{\circ} \mathrm{C}\right)$} & 54.5 & 54.5 & 54.5 & 56.0 & 56.0 & 56.0 \\
\hline & \multirow{2}{*}{1} & Load (ton) & 5.6227 & 8.2210 & 13.4908 & 15.8117 & 17.2699 & 19.4011 \\
\hline & & Deflection (mm) & 0.4144 & 0.4988 & 0.6023 & 0.7280 & 0.7828 & 0.8861 \\
\hline & \multirow{2}{*}{2} & Load (ton) & 5.6329 & 8.2067 & 13.5867 & 15.8403 & 17.2250 & 19.3236 \\
\hline & & Deflection (mm) & 0.3703 & 0.4758 & 0.5681 & \begin{tabular}{|l|}
0.6929 \\
\end{tabular} & 0.7457 & 0.8519 \\
\hline & \multirow{2}{*}{3} & Load (ton) & 5.6553 & 8.2026 & 13.6499 & 15.8729 & 17.1700 & 19.4317 \\
\hline & & Deflection (mm) & 0.3631 & 0.4618 & 0.5535 & 0.7110 & 0.7646 & 0.8138 \\
\hline & \multirow{2}{*}{4} & Load (ton) & 5.6329 & 8.2169 & 13.4766 & 15.8545 & 17.1904 & 19.2665 \\
\hline & & Deflection (mm) & 0.3682 & 0.4578 & 0.5553 & 0.7097 & 0.7513 & 0.7687 \\
\hline & \multirow{2}{*}{5} & Load (ton) & 5.6268 & 8.2169 & 13.5724 & 15.9218 & 17.1802 & 19.5092 \\
\hline & & Deflection (mm) & 0.3501 & 0.4515 & 0.5637 & 0.7056 & 0.7109 & 0.7705 \\
\hline
\end{tabular}

The deflection test given in Table 2 needs to be corrected with respect to the surface temperatures and the weather during the test. The amount of correction factors can be seen in Table 3. Then, one should correct the pavement deflection data in Table 2 by multiplying them with both correction factors in Table 3, so that the results can be presented in Table 4, which are the corrected deflection values of the pavement under variation of loadings.
Table 3. Correction factors for surface temperatures and weather during the test

\begin{tabular}{|c|c|c|c|c|c|c|c|}
\hline $\begin{array}{c}\text { Name of } \\
\text { Road }\end{array}$ & $\begin{array}{c}\text { Data } \\
\text { Recorded }\end{array}$ & \multicolumn{3}{|c|}{ 1st Test } & \multicolumn{3}{c|}{ 2nd Test } \\
\hline \multirow{2}{*}{ Arterial } & Temp. $\left({ }^{\circ} \mathrm{C}\right)$ & 56 & $\mathrm{Ft}$ & 0.70 & 60 & $\mathrm{Ft}$ & 0.67 \\
\cline { 2 - 8 } & Season & rainy & $\mathrm{Ca}$ & 0.90 & rainy & $\mathrm{Ca}$ & 0.90 \\
\hline \multirow{2}{*}{ Collector } & Temp. $\left({ }^{\circ} \mathrm{C}\right)$ & 54.5 & $\mathrm{Ft}$ & 0.72 & 56 & $\mathrm{Ft}$ & 0.70 \\
\cline { 2 - 8 } & Season & rainy & $\mathrm{Ca}$ & 0.90 & rainy & $\mathrm{Ca}$ & 0.90 \\
\hline
\end{tabular}

$\mathrm{Ft}=$ temperature correction

$\mathrm{Ca}=$ weather correction

Table 4. The corrected deflection values of the pavement under variation of loadings

\begin{tabular}{|c|c|c|c|c|c|c|c|c|}
\hline \multirow{2}{*}{$\begin{array}{c}\text { Name of } \\
\text { Road }\end{array}$} & \multirow{2}{*}{$\begin{array}{c}\text { No. of } \\
\text { Test }\end{array}$} & \multirow{2}{*}{ Data Recorded } & \multicolumn{6}{|c|}{ Variations of Load } \\
\hline & & & 1 & 2 & 3 & 4 & 5 & 6 \\
\hline \multirow{10}{*}{ Arterial } & \multirow{2}{*}{1} & Load (ton) & 5.6941 & 8.3331 & 13.8314 & 16.1645 & 17.5350 & 19.6642 \\
\hline & & Deflection (mm) & 0.1645 & 0.2013 & 0.2517 & 0.2796 & 0.3063 & 0.3293 \\
\hline & \multirow{2}{*}{2} & Load (ton) & 5.6553 & 8.3331 & 13.8355 & 16.0993 & 17.5269 & 19.7315 \\
\hline & & Deflection (mm) & 0.1212 & 0.1590 & 0.2468 & 0.2847 & 0.2975 & 0.3262 \\
\hline & \multirow{2}{*}{3} & Load (ton) & 5.5758 & 8.3005 & 13.7784 & 16.2216 & 17.6574 & 19.8865 \\
\hline & & Deflection (mm) & 0.1162 & 0.1476 & 0.2614 & 0.2959 & 0.2999 & 0.3377 \\
\hline & \multirow{2}{*}{4} & Load (ton) & 5.6288 & 8.2883 & 13.6193 & 16.0891 & 17.4188 & 19.6051 \\
\hline & & Deflection (mm) & 0.1216 & 0.1444 & 0.2615 & 0.2684 & 0.2978 & 0.3372 \\
\hline & \multirow{2}{*}{5} & Load (ton) & 5.6411 & 8.2964 & 13.6336 & 16.0524 & 17.4188 & 19.6336 \\
\hline & & Deflection (mm) & 0.1342 & 0.1503 & 0.2471 & 0.2997 & 0.3010 & 0.3515 \\
\hline \multirow{10}{*}{ Collector } & \multirow[b]{2}{*}{1} & Load (ton) & 5.6227 & 8.2210 & 13.4908 & 15.8117 & 17.2699 & 19.4011 \\
\hline & & Deflection (mm) & 0.2670 & 0.3214 & 0.3881 & 0.4595 & 0.4941 & 0.5593 \\
\hline & \multirow{2}{*}{2} & Load (ton) & 5.6329 & 8.2067 & 13.5867 & 15.8403 & 17.2250 & 19.3236 \\
\hline & & Deflection (mm) & 0.2386 & 0.3066 & 0.3660 & 0.4373 & 0.4707 & 0.5377 \\
\hline & \multirow{2}{*}{3} & Load (ton) & 5.6553 & 8.2026 & 13.6499 & 15.8729 & 17.1700 & 19.4317 \\
\hline & & Deflection (mm) & 0.2340 & 0.2976 & 0.3566 & 0.4488 & 0.4826 & 0.5136 \\
\hline & \multirow{2}{*}{4} & Load (ton) & 5.6329 & 8.2169 & 13.4766 & 15.8545 & 17.1904 & 19.2665 \\
\hline & & Deflection (mm) & 0.2372 & 0.2950 & 0.3578 & 0.4480 & 0.4742 & 0.4852 \\
\hline & \multirow[b]{2}{*}{5} & Load (ton) & 5.6268 & 8.2169 & 13.5724 & 15.9218 & 17.1802 & 19.5092 \\
\hline & & Deflection (mm) & 0.2256 & 0.2909 & \begin{tabular}{|l|}
0.3632 \\
\end{tabular} & 0.4453 & 0.4487 & 0.4863 \\
\hline
\end{tabular}



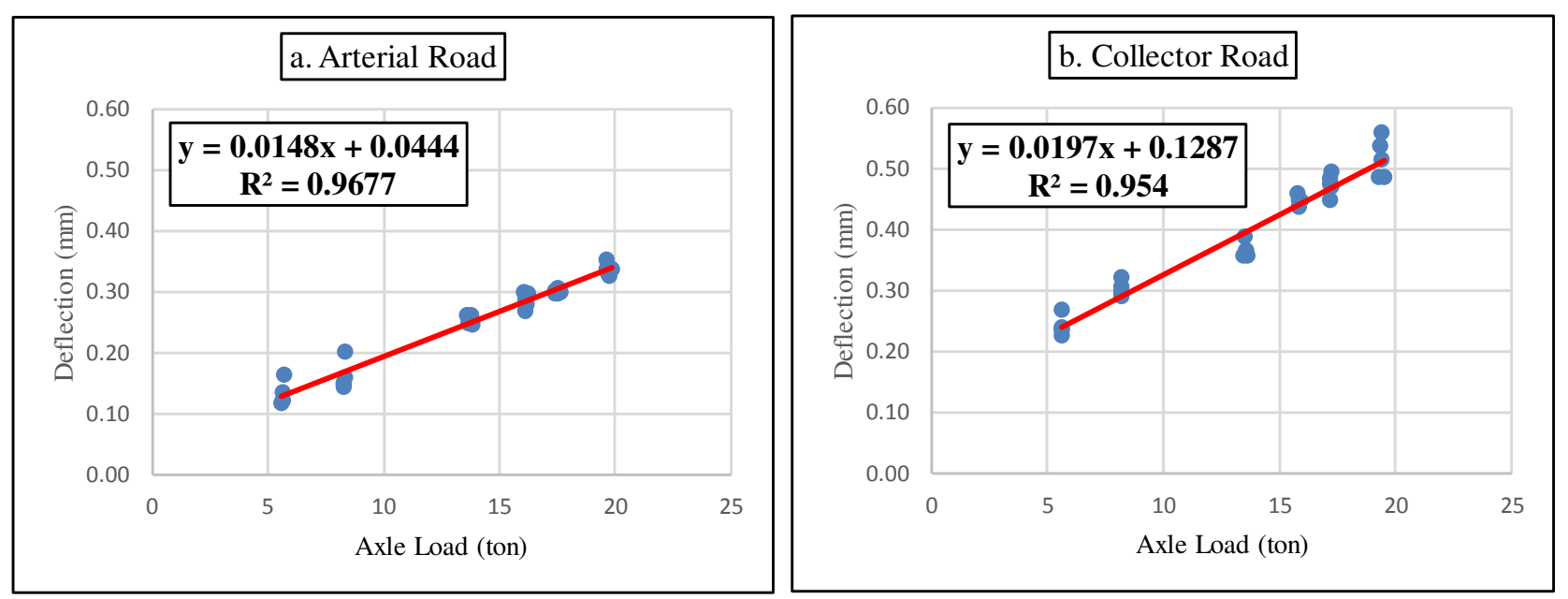

Figure 3. Regression analyses results for arterial and collector highways

The next step was then to make the mathematical regression lines that fits all the corrected data and the results are given in Figure 3. The Y-axis represents the corrected pavement deflections and the $\mathrm{X}$-axis represents the axle loadings. It is apparent that linear lines will fit the mathematical regression rather satisfactorily, since the $\mathrm{R}^{2}$ values are greater than 0.9 . This means that the above correlations of pavement deflections vs. vehicle axle loadings could be used to predict the actual flexible pavement deflections under varieties of pavement loadings for many similar highways in Indonesia

The above regression results can be used to correlate the actual deflection values of flexible pavement under overloaded heavy vehicles by merely measuring the deflection using the standard FWD test. The actual pavement deflection under overloaded load should therefore be used in designing the pavement overlay thickness, so that stronger pavement design is obtained.

It should be noted that overloading on the collector roads will cause higher deflection values than that on the arterial roads. This is because the arterial roads in general are thicker, stronger and having higher stiffness that those of the collector roads. This also means that the impact of overloading on thinner pavement will be more pronounced than that on thicker pavement, so that overloading will cause more severe damages on thinner and weaker pavement than their impact on thicker and stronger pavement.

From the statement in the last sentence in the above paragraph, more important facts could be deducted that overloading on pavement is not merely to cause more severe damages to the thinner pavement, but it also suspected that the values of Equivalent Axle Load, EAL, for thinner and weaker pavements should be much higher than those in thicker and stronger pavement. This is contrary to the existing knowledge that the value of EAL can be represented by the same power factor, i.e. the power of 4 by Bina Marga 2005 [1], regardless the pavement condition. Field evidences showed that for weaker pavement, the power should be much higher than 4; while for stronger pavement, the power may be less than 4. However, more conclusive evidences of research to support the above finding will be given in separate paper, in future publication.

\section{CONCLUSSION}

Based on the analyses given previously, it can be concluded as follows:

1. The mathematical model to predict to predict deflections of pavement under variety of truck axle loadings can be formulated as follows:

$>$ For arterial highway of this study :

$$
\mathrm{Y}=0.0148 * \mathrm{X}+0.0444
$$

$>$ For collector highway of this study :

$$
\mathrm{Y}=\mathrm{Y}=0.0197 * \mathrm{X}+0.1287
$$

in which $\mathrm{Y}=$ values of maximum pavement deflection under the vehicle tire, in $\mathrm{mm}$; and $\mathrm{X}=$ values of vehicle axle loadings, in tons.

2. The above equations could also be used to find the actual pavement deflection under much heavier axle loadings to represent the overloaded condition of roads and highways in Indonesia. The much larger values of pavement deflection should be used instead in designing pavement overlay thicknesses.

3. The mathematical formulations also showed that overloading on weaker and thinner pavement will cause more severe deflections, hence more severe damages, than overloading on thicker and stronger pavements. Therefore, it is suspected the power factor to be used in correlating the EAL values in weaker pavement should be much higher than those in stronger pavement.

\section{REFERENCES}

[1] Departemen Pekerjaan Umum (2005), Indonesian Dept. of Public Work, Highway Division. "Pedoman Perencanaan Tebal Lapis Tambah Perkerasan Lentur Dengan Metode Lendutan (Pd T-05-2005-B)" ("Guidance of Designing of pavement Overlay Using Deflection Method”), Direktorat Jenderal Bina Marga.

[2] AASHTO, (1993), AASHTO Guide for Design of Pavement Structures, American Association of State 
Highway and Transportation Officials, Washington, D.C.

[3] Asphalt Institute (1981). Thickness Design, Asphalt Pavement Structure for Highway and Streets (MS-1): College Park, Maryland 20740,USA.

[4] FHWA (U.S. Federal Highway Administration) (2003). Distress Identification Manual for the Long-Term Pavement Performance Program. Publication: No. FHWA-RD-03-031, Washington D.C.

[5] Huang, Y.H. (2004). Pavement Analysis and Design. Pearson Prentice Hall, Upper Saddle River, NJ.

[6] Kosasih, D. (2003). The Effects of Pavement Structure Modeling and Deflection Bowl Analysis on Calculated Layer Moduli. Journal of the Eastern Asie Society for Transportation Studies. Vol 5: 927-939.

[7] Shell International Petroleum Company (1978). Shell Pavement Design Manual:Asphalt Pavements and Overlay for Road Traffic. Shell International Petroleum Co.: London.
[8] Sutikno, Sentot dan Mochtar, IB, (1991), "Studi Lapangan Tentang Pengaruh Beban Gandar dan Temperatur Terhadap Lendutan Perkerasan Jalan Tol Surabaya-Gempol" ("Field Study on the Effects of Axle Loads and Temperature Against the Deflections of Pavement of the Surabaya-Gempol Toll Road"), Tugas Akhir S-1 ITS. Jurusan Teknik Sipil, FTSP-ITS, Surabaya. (Final Project Report, Dept. of Civil Engineering, ITS, Surabaya).

[9] Prastyanto, C, A,. et. al. (2012), "Perencanaan Jalan Akses Pabrik Semen Tuban" ("Design of Access Road of Tuban Cement Factory"), Design Report, PT. Semen Gresik, Tuban, Jawa Timur.

[10] Danida dan Pusat Litbang Jalan (1990). Study of Improved Bearing Capacity Evaluation and Strengthenen Design of Road. Technical Report No. 2. FWD Calibration, Bandung: Puslitbang P.U.

[11] Dynatest FWD/HWD Test Systems, (2008), “Owner's Manual Version 2.4.2”, Dynatest International A/S. 